\title{
TOTEK (Türk Ortopedi ve Travmatoloji Eğitim Konseyi) ve EBOT (European Board of Orthopaedics and Traumatology Fellowship) yeterlik sınavlarının karşılaştırılması
}

\section{Comparison of TOTEK (Turkish Orthopedics and Traumatology Education Council) and EBOT (European Board of Orthopaedics and Traumatology Fellowship) proficiency exams}

\author{
Emel Gönen ${ }^{1}$, Haluk Berk² \\ ${ }^{1}$ Ankara Dışkapı Eğitim Araştırma Hastanesi, Ortopedi ve Travmatoloji Kliniği, Ankara \\ ${ }^{2}$ Dokuz Eylül Üniversitesi, Tıp Fakültesi, Ortopedi ve Travmatoloji Anabilim Dalı, İzmir
}

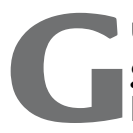
ünümüz bilim ve teknolojisinin yüksek ivmeli gelişimiyle birlikte, kas-iskelet sistemi hastalıkları ve tedavi seçenekleri hakkındaki bilgiler giderek genişlemekte ve bu durum, hem ortopedi ve travmatolojinin klinik pratiğinde hem de temel bilimler alanında geniş bir güncel teorik bilgi gerektirmektedir. ${ }^{[1]}$ Tıp alanındaki yeterlik (board) sınavlarında; yetkin ve güvenli hekimleri belirlemek amacıyla güncel bilgi, kavram ve prensipleri uygulama becerisini ölçmek - değerlendirmek hedeflenmektedir. Yeterlik sınavları bilgiyi ölçme ve değerlendirme işlevlerinin yanı sıra, yeterlik için istenen kapsamı sunması nedeniyle, bu sınavlara yeniden girecek adaylar için şekillendirici olma özelliğine de sahiptir. Bu amaçlarla, ülkemizde TOTEK (Türk Ortopedi ve Travmatoloji Eğitim Konseyi) yeterlik sınavı, Avrupa'da ise EBOT Fellowship (European Board of Orthopaedics and Traumatology Fellowship) yeterlik sınavları uygulanmaktadır.

Gerek TOTBID bünyesinde bulunan TOTEK, gerekse UEMS (The European Union of Medical Specialists)'de yer alan EBOT; tıp eğitimi ve uygulamasının ölçme ve değerlendirilmesi alanında uzun yıllara dayanan bir tecrübeye sahiptir. TOTEK, her yıl ortalama 800 civarı asistanın katıldığı Uzmanlık Eğitimi Geliştirme Sınavı (UEGS)'yi 2009'dan itibaren, yaklaşık 150 uzman ve asistanın katıldığı yeterlik sınavlarını ise 2003 'ten beri düzenlemektedir. ${ }^{[2-5]}$ EBOT, yine aynı şekilde, tüm Avrupa ülkelerini bir araya getirerek geçtiğimiz yıl 120 asistanın katıldığı EBOT Interim sınavlarını 2011'den itibaren ve en son 80 uzman+asistanın katıldığı EBOT Fellowship sınavlarını ise 2001 'den bu yana düzenlemektedir. ${ }^{[6]}$
Ülkemizde 2003-2014 yılları arasında TOTBIDTOTEK tarafindan organize edilmiş olan 12 TOTEK yeterlik sınavında, 489 meslektaşımız yeterlik sertifikası alarak TOTEK üyesi olmaya hak kazanmıştır. Ulusal Yeterlik Sınavlarında (TOTEK) başarılı olan hekimlerden, daha sonra Avrupa (EBOT - European Board of Orthopedics and Traumatology Fellowship) yeterlik sınavına da başvuran meslektaşlarımız bulunmaktadır. Dolayısıyla, TOTEK üyesi olup da 2003-2014 yılları arasında EBOT sınavına girerek başarılı olan ve Avrupa board sertifikası almaya hak kazanmış 29 meslektaşımız vardır (Tablo 1).

\section{SINAV AŞAMALARI VE SINAV KOMISYONU}

TOTEK yeterlik sınavı iki aşama olup, her yıl sonbaharda düzenlenmektedir. Sınavın ilk aşamasını "objektif yapılandırılmış çoktan seçmeli sorular" (Objective Structured Multiple-Choice Question - OSMCQ)'dan oluşan yazılı sınav; ikinci aşamasını ise objektif yapılandırılmış klinik muayene (Objective Structured Clinical / Practical Examination - OSCE/OSPE) içeren sözlü sınav oluşturmaktadır. EBOT sınavı da, TOTEK yeterlik sınavları gibi yazılı (Haziran) ve sözlü (Ekim) olmak üzere iki aşamalı yapılmaktadır. Ancak önümüzdeki yıllarda üçüncü aşama olarak klinik pratik sınavın da eklenmesi düşünülmektedir. ${ }^{[7]}$

Ulusal Yeterlik Sınavı yapan Avrupa ülkelerinin kullandığı yöntemler araştırıldığında ise; EFORT anketine göre; \%46,7'sinde çoktan seçmeli sorular (MCQ) sınavın bir parçası iken, \%73'ünde ek olarak sözlü sınav, \%40'ında objektif yapılandırılmış klinik muayene (OSCE) kullanılmakta; \%26,6'sında ise sınavın üçüncü

- Illetişim adresi: Dr. Emel Gönen, Asmabahçe G-30, Koru, Ankara

Tel: 0542 - 4364848 e-posta: emelgonen@yahoo.com

- Geliș tarihi: 24 Ekim 2014 Kabul tarihi: 24 Ekim 2014 
Tablo 1. TOTEK sınavlarında ve Türkiye'den EBOT sınavlarında başarılı olan aday sayıları

\begin{tabular}{lccc}
\hline Sinav Yılı & TOTEK* & EBOT** & $* * *$ \\
\hline 2014 & 63 & 7 & \\
2013 & 63 & 4 & 3 \\
2012 & 52 & 5 & 2 \\
2011 & 49 & 3 & 5 \\
2010 & 47 & 3 & 1 \\
2009 & 38 & 1 & 2 \\
2008 & 29 & 2 & 3 \\
2007 & 40 & - & 4 \\
2006 & 24 & 4 & - \\
2005 & 28 & - & 4 \\
2004 & 40 & - & 4 \\
2003 & 16 & - & 1 \\
Toplam & 489 & 29 & 29 \\
\hline
\end{tabular}

* ilgili yılda yapılan TOTEK sınavında başarııı olan aday sayısı.

** ilgili yılda yapılan EBOT sınavında başarılı olan aday sayısı.

** *ilgili yılda TOTEK üyeliği kazanmış olanlardan EBOT sertifikasına sahip üye sayısı.

aşaması klinik değerlendirme olmaktadır. Ülkelerin \%40'ında, karışık vakalardan oluşan bir portfolyo ön şarttır. ${ }^{[8]}$

TOTEK yeterlik sınavları (TOTBID-TOTEK), 2002 yılından itibaren TOTEK sertifikası almaya hak kazanan TOTEK üyesi meslektaşlarımız arasından kurulan komisyon tarafından yapılmaktadır. 2003-2009 yılları arasında ilk aşama sınavı ÖSYM aracılığıyla yapılırken, ÖSYM'nin düzenlemiş olduğu diğer bazı sınavlarda ortaya çıkan güvenlik sorunları nedeniyle, TOTEK tarafından değişiklik kararı alınmıştır. 2010 tarihinden itibaren sınavın tüm aşamaları TOTBID-TOTEK sorumluluğunda ve Ege Üniversitesi Tıp Fakültesi Tıp Eğitimi Anabilim Dalı danışmanlığında gerçekleşmektedir.

EBOT sınavı, üye ülkelerin eğitim konseyi - yeterlik kurulları veya uzmanlık dernekleri tarafindan bildirilen uluslararası bir komisyon tarafindan, Dr. Jorge Mineiro başkanlığında yapılmaktadır. ${ }^{[9,10]}$ Başka ülkelerdeki yeterlik sınavlarına göz gezdirdiğimizde; 29 ülkeyi (Tablo 2) kapsayan EFORT anketi sonuçlarına göre, ülkelerin \%79,3'ünde ulusal bir board sınavı uygulandığı izlenmektedir. Bu ülkelerde sınavları düzenleyen organizasyonlar \%45,8'inde devlete ait kurumlar (Sağlık Bakanlığı vb.) iken, \%29,2'sinde profesyonel organizasyonlar (ortopedi dernekleri), \%25'inde bağımsız ulusal board'lar, \%25'inde üniversiteler sınavı üstlenmektedir. ${ }^{7,8]}$
Tablo 2. EFORT ortopedi asistan eğitim anketinde yer alan ülkeler (Orthopaedic Residency Training Survey - Federation of Orthopaedic Trainees in Europe, FORTE).

$\begin{array}{lll}\text { Almanya } & \text { Hırvatistan } & \text { Macaristan } \\ \text { Avusturya } & \text { Hong-Kong } & \text { Norveç } \\ \text { Belçika } & \text { İngiltere } & \text { Portekiz } \\ \text { Brezilya } & \text { İrlanda İspanya } & \text { Romanya } \\ \text { Çin } & \text { Isveç } & \text { Şili } \\ \text { Danimarka } & \text { İtalya } & \text { Slovakya } \\ \text { Estonya } & \text { Kıbrıs } & \text { Türkiye } \\ \text { Finlandiya } & \text { Lübnan } & \text { Yunanistan } \\ \text { Fransa } & \text { Lüksemburg } & \\ \text { Hindistan } & & \end{array}$

Tüm Avrupa ülkelerinde yeterlik sertifikasını düzenleyen kurumların dağılımı incelendiğinde ise; ülkelerin \%43,3'ünde sağlık bakanlığı, \%33,3 ulusal boardlar, \%23 üniversiteler, \%6,7 uzmanlık dernekleri, \%6,7 ulusal medikal birliklerin üstlendiği görülmektedir. ${ }^{[7,8]}$

\section{SINAV BAŞVURUSU}

TOTEK sınavına Türk vatandaşları katılabilmekte; EBOT sınavına Avrupa Birliği (Norveç, İsviçre ve AB'ye yeni katılan ülkeler dahil) vatandaşlarının yanında, Avrupa Birliği'ne üye olmayan ancak UEMS (Specialist Section of Orthopaedics and Traumatology) assosiye üyesi olan Türkiye, Hırvatistan, İsrail vatandaşları da bazı şartları sağlayarak başvurabilmektedir.

TOTEK ilk aşama sınavına, 2012 yılından itibaren son yıl asistanları da başvurabilmektedir. Son yıl asistanlarının sınava alınması kararıyla, yıllara göre asistan katılımında oldukça artış gözlenmiştir. ${ }^{[5]}$ Son yıl asistanları, EBOT sınavı ilk aşamasına da girebilmektedir. Ancak her iki sınavda da, ikinci aşama için bu adayların asistanlık eğitimini tamamlamış olması şartı aranmaktadır.

TOTEK board sınavlarına katılımda kişi sayısı yönünden sınırlandırma olmayıp, başvuru sayısına göre ihtiyaç durumunda, sınav merkezleri ve sınav yapıcılarda anında düzenlemeye gidilebilmektedir. EBOT sınavına başvuru sayısına maksimum 80 kişi ile sınırlama getirilmiştir. ${ }^{[11]}$ TOTEK sınav başvuruları sonbaharda olup, 2014 yılı ilk aşama Eylül, ikinci aşama Ekim ayı olarak belirlenmiştir. Başvuruda, kimlik, fotoğraf, yanı sıra uzmanlık belgesi ve asistanlar için asistanlığa başlama yılı belgeleri istenmektedir. EBOT ilk aşama için başvurular her yıl mart ayı sonunda yapılmaktadır; başvuru için özgeçmiş, pasaport ve uzmanlık belgesi örneği ve çalıştığı kurumun anabilim dalı başkanı tarafından verilen yapılandırılmış referans mektubu gerekmektedir. ${ }^{[11]}$ 
2014 itibariyle, TOTEK sınavının ilk aşaması 150,00 TL, ikinci aşaması ücretsizdir. EBOT sınavı ilk aşama başvuru ücreti 300 Euro, ikinci aşama ise 500 Euro'dur ve ek olarak yurtdışı sözlü sınavın yol ve konaklama giderleri de göz önüne alınmalıdır.[11]

\section{SINAV MERKEZLERI}

\section{i. ilk aşama sınav merkezleri}

TOTEK yeterlik sınavının ilk aşaması 2003-2012 yılları arasında, sadece Ankara'da yapılırken, 2013'den itibaren üç ildeki (Ankara, İstanbul ve İzmir) merkezlerde eş zamanlı olarak yapılmaktadır. Sınavın üç ayrı merkezde yapılması, sınava katılımı oldukça arttırmış$\operatorname{tir}\left(2013\right.$ 'te \%40). ${ }^{[5]}$

EBOT sınavının ilk aşaması ise, bazı Avrupa ülkelerinde bulunan profesyonel Pearson VUE test merkezlerinde, bilgisayar üzerinden yapılmaktadır. Aday, Mart ayında başvurusunu yapıp sınava girebilirliği onaylandıktan sonra, Nisan-Mayıs ayları arasında Avrupa'da hangi Pearson VUE merkezinde gireceğini kendisi seçmektedir. ${ }^{[12]}$ Türkiye'de bu şekilde aktif olarak sınav hizmeti vermekte olan merkez sayısı altı olup, Ankara (1), İstanbul (4) ve İzmir'de (1) yer almaktadır. Sınav, hem çevrimiçi kamera takibi ile Avrupa merkezinden sürekli izlenmekte hem de Türkiye'deki teknik bir ekip tarafından sıkı gözetim altında yapılmaktadır. Adaylar bu merkezlerde sınava girerken, tüm eşyalarını kilitli dolaplara bırakmakta; sınav salonuna kimlik, kalem, telefon, içecek vb. alınmasına veya gözetmenle iletişime izin verilmemektedir. Sınav günü aday, sınav programını gözetmenin vereceği şifre ile bağlanarak yüklemektedir. Bu aşamadan sonra, aynı bilgisayardan başka bir bilgiye erişim kilitlenmektedir. Cevaplar, internet veya elektrik kesintisi durumunda kaybolmayacak şekilde, adayın bilgisayarında yedeklenmekte, sınav sona erdiğinde son hali sisteme yüklenmektedir. Sınava itiraz ve yazışmalar sistem üzerinden yapılmaktadır. ${ }^{[12,13]}$

Böyle sistemlerin aynı anda çevrim-içi sınav yapmak üzere alabileceği maksimum kişi sayısı oldukça sınırlıdır ve seçilecek bilgisayar programlarına bağlı olarak maksimum aday sayısı 8-15 kişidir. Ayrıca, sistem elektronik-güvenlik açısından çok büyük yatırımlar gerektirmektedir. ${ }^{[13,14]}$

\section{ii. İkinci aşama sınav merkezleri}

TOTEK sınavının ikinci aşaması 2003-2009 yılları arasında İzmir'de, 2009-2011 arası TOTBID merkezinde yapılmıştır; 2012 yılından beri Ankara Üniversitesi Tıp Fakültesi Morfoloji Binası'nda düzenlenmektedir. TOTEK board sınavlarının her iki aşamasında da sınav yapıcı olarak TOTEK sertifikalı üyeler görev almaktadır. Sınavların tüm organizasyon masraflarını TOTBID üstlenmektedir. EBOT ikinci aşama (sözlü) sınavı ise 2000 yılından beri, her yıl başka bir Avrupa ülkesinde olmak üzere, Ekim ayının ilk hafta sonunda yapılmaktadır.

\section{SINAV ÖZELLIKLERi}

\section{i. Illk Aşama}

Bu aşamada, adayın bilgi ve karar verme becerisi ölçülmektedir. ${ }^{[15]}$ TOTEK birinci aşama sınavı için 2011 yılından itibaren, 100 sorudan oluşan tek doğru cevaplı yapılandırılmış çoktan seçmeli sınav (Objective Structured Multiple Choice Questions - OSMCQ) uygulanmaktadır. Test için standart kurgularken, hangi tip standardın (relatif-kesin) seçileceğine ve kurgulamanın yöntemine karar verilmesi, karar vericilerin belirlenmesi ve bir araya gelmesi, geçme noktasının belirlenmesi ve daha sonra nasıl hareket edileceğinin planlanması gerekmektedir. ${ }^{[16]}$ Yapılandırılmış çoktan seçmeli sınavda; sorulmak istenen bilgi, soruları konulara eşit oranda dağılımı ve zorluk dereceleri önceden belirlenir. Bu amaçla TOTEK sınavında; sorulan bilgilerin çekirdek eğitim programının dışına çıkmamasına, uzmanlık üstü dallara ait bilgiler içermemesine, birden çok çeldirici içermemesine ve soruların tüm konulara dağılımı belirlenen oranlarda olmasına dikkat edilmektedir. ${ }^{[17]}$ Adayın ilk aşamada başarılı olabilmesi için soruların en az \%60'ına doğru cevap verebilmesi öngörülmektedir.

Sınav soruları, TOTEK üyeleri ve alt dal dernekleri tarafından görevlendirilen üyelerin hazırladığı bir soru havuzundan, TOTEK yönetim kurulu tarafından seçilmektedir. Geçmiş yıllardan havuzda olan sorular yeni kaynaklara göre yeniden gözden geçirilmektedir. ${ }^{[1]}$ Önerildiği gibi; TOTEK sınavının da öncelikle Çekirdek Eğitim Programı kapsamındaki konuları içermesine dikkat edilerek, bir belirtke tablosu (blue print) rehberliğinde, ${ }^{[18]}$ yedekli 100 adet soru seçilmektedir. Hangi başlıktan kaç soru sorulması önceden planlanmış ve adaylara TOTBiD web sayfasından ve Ortopod'dan duyurulmuştur. [1] Soruların ortopedi ve travmatolojinin tüm alt alanlarına göre dağılımının her yıl benzer yoğunluklarda olmasına dikkat edilmektedir. Örneklemek gerekirse, 2014 için bu dağılım; Temel Bilimler (10), Pediatrik Ortopedi (13), Travma (30), Üst Ekstremite Cerrahisi (11), Alt Ekstremite Cerrahisi (11), Artroskopik Cerrahi ve Spor Travmatolojisi (6), Erişkin Rekonstrüktif Cerrahi ve Artroplasti (6), Omurga Cerrahisi (6), Kas İskelet Sistemi Enfeksiyonları (3) ve Tümörleri (4) alanında sorular şeklindedir. Belirlenen alt alanların 
kendi içinde de ayrıca o dala özgü konu başlıkları belirlenmekte ve çekirdek müfredat programındaki her konudan soru sorulmaya çalışılmaktadır.

Her bir sorunun zorluk derecesi öncelikle soruyu hazırlayan TOTEK üyesi tarafından öngörülerek belirtilmektedir. Sorular sınav komisyon başkanı ve TOTEK yönetim kurulu üyeleri tarafından birkaç oturumda seçilmektedir. Sınav komisyonu yeniden her bir soruyu inceleyerek zorluk derecesini değerlendirmekte, son hali bir komisyon üyesi üzerinde denenmektedir. İyi bir yeterlik sınavında, klinik yaklaşımı sergileyen öyküye dayalı, şekil ve radyolojik tetkikler içeren probleme dayalı sorular (POQ) tüm soruların en az \%30'unu oluşturması gerekmektedir. ${ }^{[17]}$ Sorular zorluk derecelerine göre eşit olacak şekilde (örneğin; 2013 için kolay [\%30], orta [\%40] ve zor [\%30]) olarak seçilmesine özen gösterilmektedir. Yeterlik sınavı bir sıralama sınavı olmadığından, birden çok çeldiricilerin yeraldığı sorular kulanılmamaktadır. Yeterlik sorgulamak için temel bilgiler sorulur; mümkün olduğunca aday yanıltılmaya çalışılmaz; soruyu herkes bilse bile ölçme-değerlendirme açısından önemlidir. Bu nedenle, iyi bir yeterlik sınavında ayırıcılık indeksi dağılımının belli oranlarda olması istenmektedir. ${ }^{[17]}$ Fakat, her sorunun gerçek ayırıcılık ve zorluk değeri ancak sınav uygulandıktan sonra bilinebilmektedir (Şekil 1) (Tablo 3). Tahmin edileceği üzere; aynı sorular daha sonraki yıllarda farklı adaylara uygulandığında, bu kez aday bilgi düzeyi değiştiğinden, aynı zorlukta/ayırıcılıkta olmamaktadır.

OSMCQ sınavlarda adaylara, kurslarla veya önceden hazırlanan kitaplarla ÇEP eğitimi tekrar verilmeli, $[17,19]$ sorular hakkında fikir sahibi olabileceği kaynaklar sunulmalı ${ }^{[19]}$ veya kaynak sayısı sınırlandırılmalıdır. ${ }^{[17,19]}$
Tablo 3. TOTEK birinci aşama ayırıcılık ve zorluk indeksleri[ $^{[5]}$

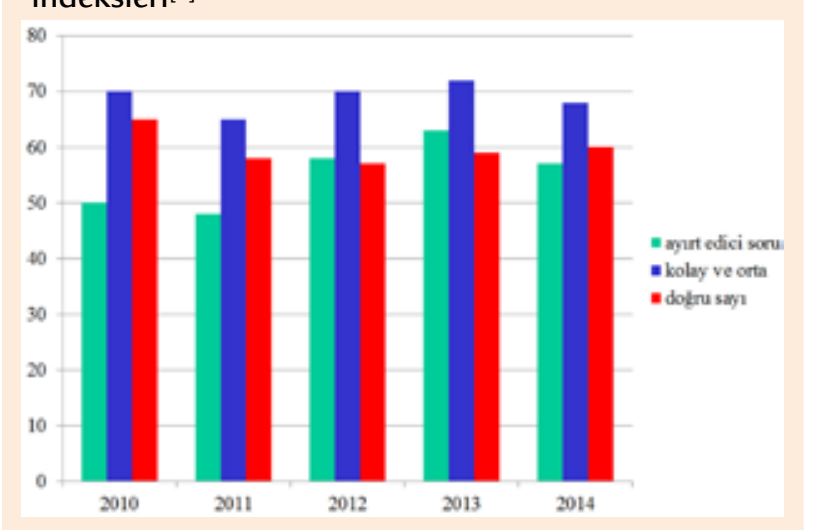

TOTEK sınavının kaynak kitapları ortopedinin temel kitapları (5-7 kitap) olup, güncel bilgiyi sınayabilmek amacıyla her sınavın, varsa yeni baskıları içermesine dikkat edilmektedir. Ayrıca, sınava kaynak olabilecek bir genel gözden geçirme kursu olan Çekirdek Eğitim Programı (ÇEP) düzenlenmekte; ÇEP programı sırasında adaylara kaynak olabilecek bir kurs kitabı ve önceki TOTEK sınavlarında çıkan sorular ve cevaplarını açıklamalarıyla düzenleyen bir sınava hazırlık kitabı da verilmektedir. ${ }^{[20]}$

Ayrıca, itirazları en aza indirebilmek amacıyla, tüm soruların kaynak doğrulamaları üç ayrı kişi tarafından tekrar tekrar yapılmakta, en son olarak da bir üyeye deneme sınavı yapılarak sınava giren bir adayın gözüyle aksayan yönler saptanmaya çalışılmaktadır. ${ }^{[5]}$ Seçilen 100 soru, Ege Üniversitesi Tıp Eğitimi

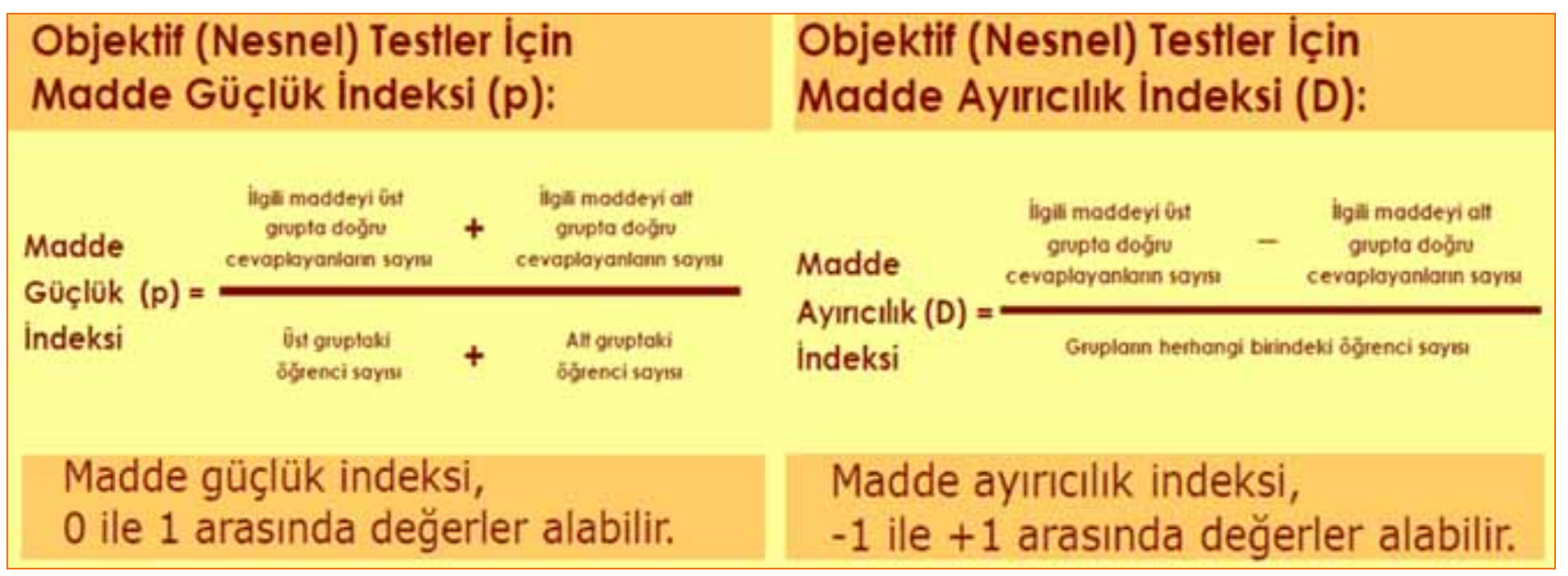

Şekil 1. Objektif testler için madde güçlük ve ayırıcılık indeksi hesaplamaları. ${ }^{[5]}$ 
Anabilim Dalı'na iletilmekte ve sorular, çoktan seçmeli soru hazırlama ilkeleri, gramer ve anlam-dil açılarından ayrıntılı biçimde değerlendirilmekte, gereğine göre düzenlenmektedir.

TOTEK sınavının soru ve cevapları, sınavdan hemen sonra TOTBID aracılığıla internet ortamında paylaşılmaktadır. ${ }^{[21]}$ Adaylara yazılı itiraz için bir süre tanınmakta ve ilgili sorular - kaynak kitaplar, bu itirazlar doğrultusunda tekrar değerlendirilmektedir. Adayların, belli bir amaç için ne kadar bildiğini değerlendiren yeterlik testlerinde kesin standartlar tercih edilir. Bu sınavlarda, TOTEK birinci ve ikinci aşamada olduğu gibi, geçer not önceden belirlenir. ${ }^{[16]}$ îlk aşama sonuçları adaylara "BAŞARILI - 60 ve üzeri not" ve "BAŞARISIZ - 60 altı not" olarak bildirilmektedir. Başarılı adaylar, beş yıl içerisinde ikinci sınava girmeye hak kazanmaktadırlar (Tablo 4).

TOTBID üyeleri soru arşivinden daha önceki yıllarda sorulmuş olan sorulara da ulaşabilmektedir. ${ }^{[22]}$ Arşiv, ÖSYM'den devir alındıktan sonraki 2009-2014 yılları arasındaki altı sınavı kapsamaktadır. Daha önceki sınavlar için hazırlanmış olan 700 civarı çoktan seçmeli soru barındıran soru bankasına ÖSYM'nin diğer tüm evrakları ile birlikte el konulduğundan, sınavlar için yeterli sayıda ve kaliteli soru hazırlığı önem kazanmıştır. Bu maksatla, TOTEK tarafından tıp eğitimcilerinin katkısıyla doğru soru hazırlama tekniklerinin de işlendiği bir soru hazırlama çalıştayı düzenlenmiştir. ${ }^{[23]}$

EBOT birinci aşama (yazılı) sınav soruları, bilgisayar ortamında ve çevrim-içi (online) olarak cevaplanmaktadır. Sınav süresi üç saat olup, çoktan seçmeli 100 sorudan oluşmaktadır (Şekil 2).[10,17] Yanlış cevabın doğruyu eksiltip eksiltmediği ve geçme notunun nasıl belirlendiği ile ilgili bir açıklama bulunmamaktadır.

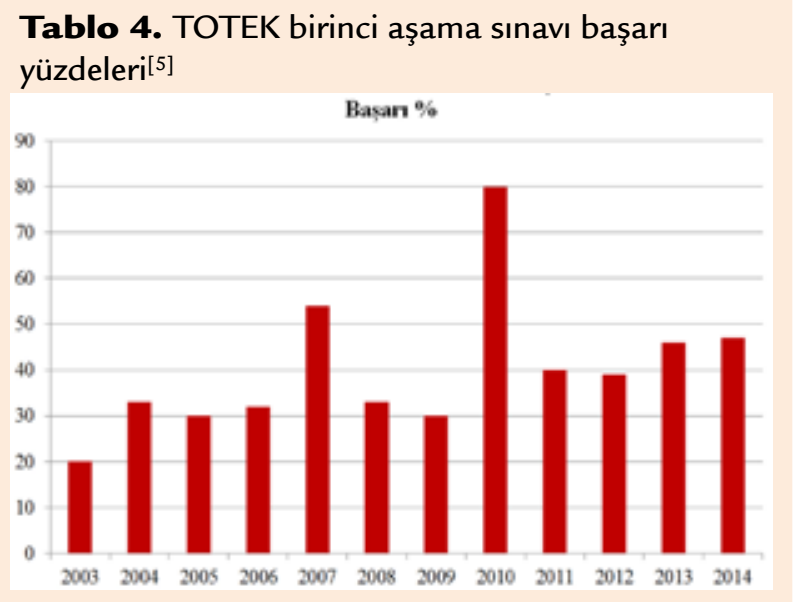

EBOT birinci aşama sınavı için, Avrupa'daki tüm ortopedi derneklerinin davet edildiği soru yazıcı bir komite tarafından, çevrimiçi veritabanı içerisinde hazırlanmış soru bankasından seçilmektedir. Üyeler, internet üzerinden eşzamanlı girerek her zaman soru ekleyebilmektedirler. Program, çoktan seçmeli, doğru-yanlış, kompozisyon stili vb. pek çok farklı tipte soruların girişine izin vermektedir. Soruya görüntü de eklenebilmekte, sorunun değişikliğe uğramış versiyonları da sistemde tutularak tüm geçmiş izlenebilmektedir. ${ }^{[12]}$ Yan dal derneklerinden temsilcilerin yazdıkları sorular yılda iki kez yapılan toplantı sırasında değerlendirilmektedir. ${ }^{[7]}$

EBOT için kaynak olarak belirlenen sabit kitaplar bulunmamakta, tüm kitap ve yayınlar referans olarak kullanılabilmektedir. ${ }^{[6]}$ TOTEK sınavlarında soruların

\section{In the treatment of osteoarthritis of the knee:}

a. physiotherapy has no value even in mild cases.

b. a high osteotomy is indicated when it affects mainly the medial compartment providing deformity is not severe.

c. knee arthrodesis is the treatment if choice in bilateral cases.

d. total knee replacement is the treatment of choice in the under 40 year age group.

e. a high tibial osteotomy will increase the range of movements in a stiff knee joint.

\section{Correct answer : b}

Şekil 2. EBOT yazılı aşama tek doğru cevaplı çoktan seçmeli soru örneği. 
konulara göre, blue print'e (tanı-klinik-tedavi) ve zorluk derecesine göre dağılımı, adaylardan elde edilen geri dönüşlere göre çok iyi bulunmuştur. ${ }^{[17]}$ Oysa EBOT sınavlarında, adaylardan geri dönüşlere göre çok nadir izlenen bir hastalık soruların \%10'unu oluştururken, bazı önemli başlıklar hiç yer almamaktadır; bu nedenlerle EBOT sınavının kapsam geçerliliği (soruların konu dağılımındaki denge) yönünden daha titiz çalışmalara gerek olduğu gözlenmektedir. EBOT birinci aşama sınav soruları ve/veya cevapları daha sonra herhangi bir yerde yayımlanmamaktadır.

\section{ii. İkinci Aşama}

EBOT ve TOTEK sözlü sınavında adaylar, bilginin yanı sıra klinik yargılama, kritik düşünme ve karar verme yetileri yönünden değerlendirilir. ${ }^{[18]} \mathrm{Bu}$ amaçla, öğrenmenin beş seviyesini (Bilgi - Kavrama - Uygulama - Analiz - Sentez - Değerlendirme) ölçmeye yönelik olacak şekilde, aşamalı ve farklı zorluk seviyelerinde sorularla çözüme ulaşma yeteneklerini göstermeleri gerekir. Miller'ın yetkinlikleri tanımladığı piramidinde de görüldüğü üzere eylemi ve performansı ölçmek, en değerli veriyi sağlamakla birlikte, ölçümü en zor olanıdır (Şekil 3). ${ }^{[18]}$

TOTEK ikinci aşama sınavları 7-9 arası istasyondan oluşmakta ve bir gün boyunca sürmektedir. Her bir istasyonda dokuz dakika süre ayrılmakta ve ilk aşamayı geçen tüm adayları aynı gün içinde sınava alabilmek amacıyla, aynı istasyonlar dört set halinde kurulmaktadır (2014 örneği: 9 istasyon = sabah anatomi ve 25 bilgisayar üzerinde üç oturum şeklinde iki CORE

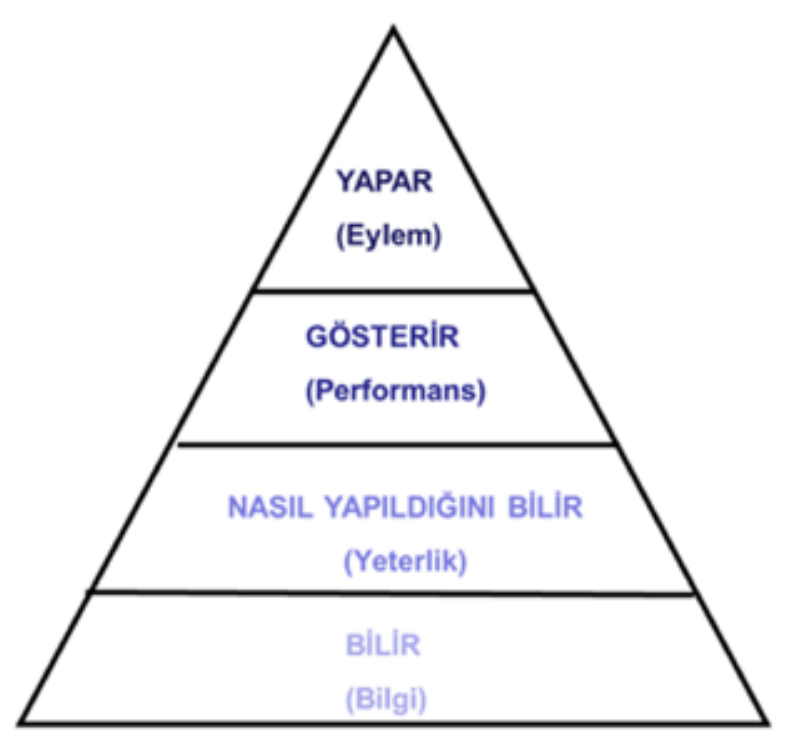

Şekil 3. Klinik değerlendirme piramidi. ${ }^{[18]}$ sorusu, radyoloji ve klinik patoloji sınavı - öğleden sonra dört grup halinde toplam 16 adet istasyonda onam, muayene, cerrahi planlama ve cerrahi beceri OSCE sınavları) (Şekil 4-7). Her istasyonda yaklaşık 15-25 soru bulunmaktadır. Muayene istasyonlarında
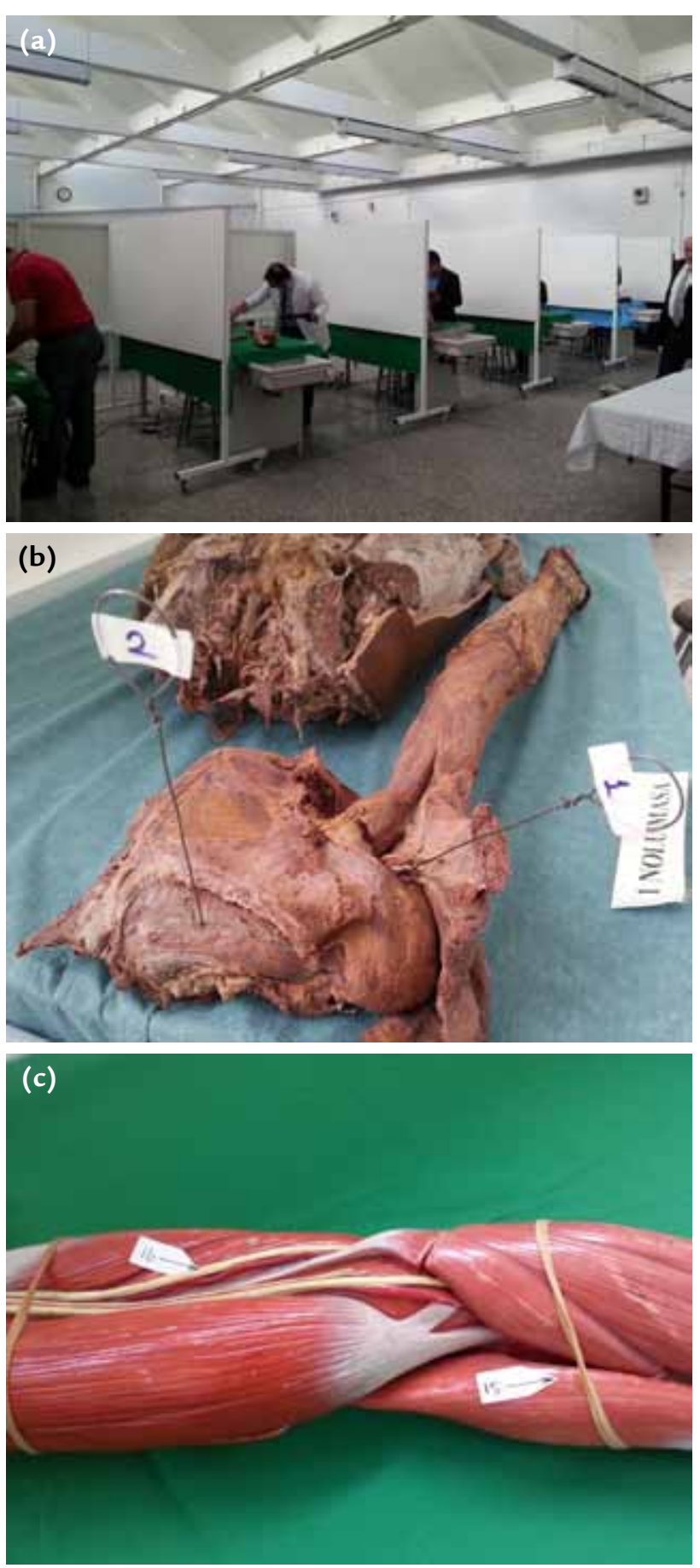

Şekil 4. a-c. TOTEK ikinci aşama sınavı anatomi istasyonları. 
ve onam istasyonlarında önceden bilgilendirilen kişiler (2014 - 8 kişi), model rolü üstlenmektedir. 2014 sınavında, her yıldakine benzer şekilde, 24'ü eğitmen olmak üzere 28 kişilik kalabalık bir kadro görev almıştır (Şekil 8 ve 9).

\section{TOTEK YETERLIK SINAVI ISTASYONLARI}

Anatomi: Anatomi anabilim dalı öğretim üyeleri tarafindan hazırlanan sorularda adaylardan, 20 adet oluşumun maket ve kadavralar üzerinde tanımaları ve yazmaları istenmektedir.

Radyoloji: Belirli sayıda görüntünün klinik bilgi eşliğinde tanınması beklenmektedir. (2013 - 14 adet - tümörler; 2014 - omurga)

Klinik-cerrahi bulguların tanınması: Belirli sayıda görüntünün klinik bilgi eşliğinde tanınması istenmektedir. (2013 - 16 adet - artroskopik cerrahi ve spor yaralanmaları; 2014 - pediatrik ortopedi)

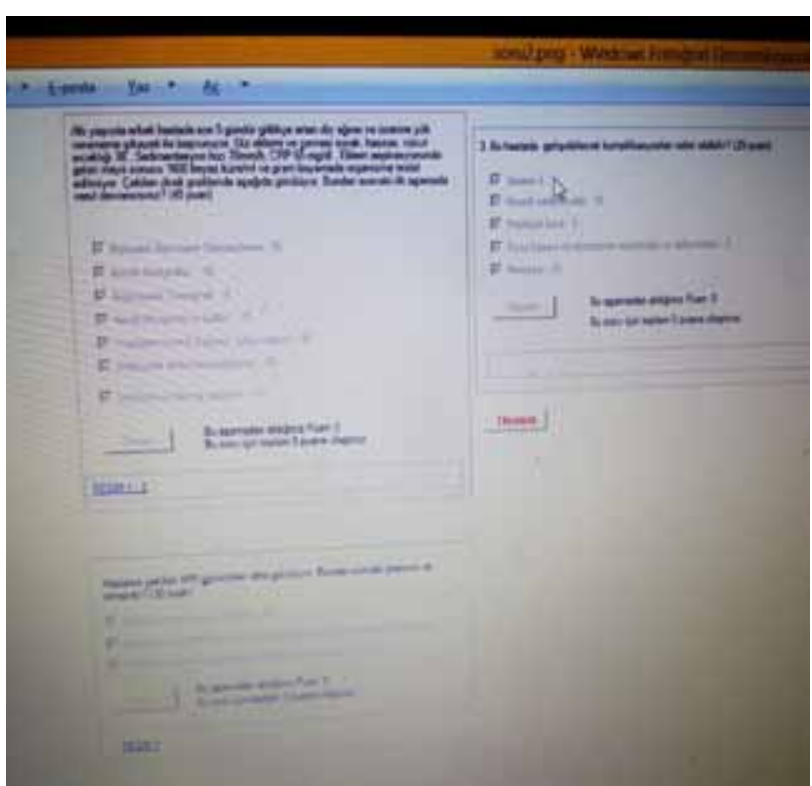

Şekil 5. TOTEK ikinci aşama sınavı CORE kart açma sorusu.
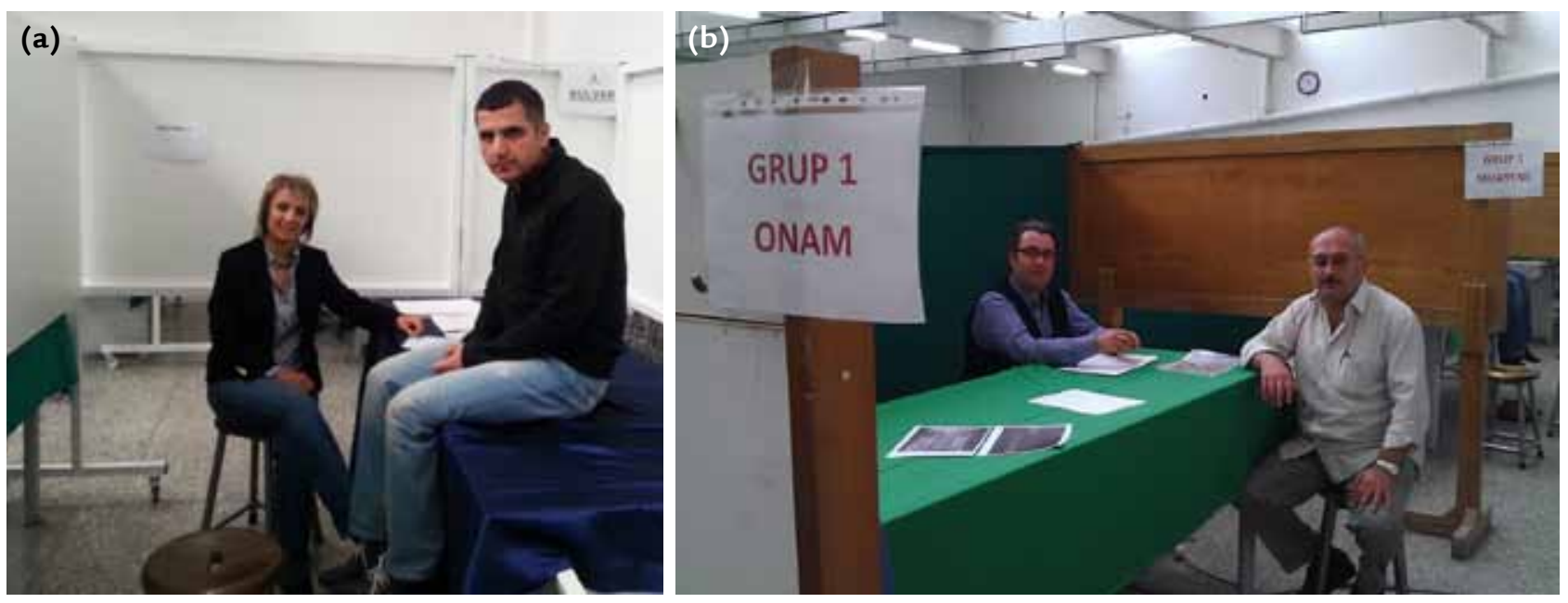

Şekil 6. a, b. TOTEK ikinci aşama sınavı onam ve muayene istasyonları.
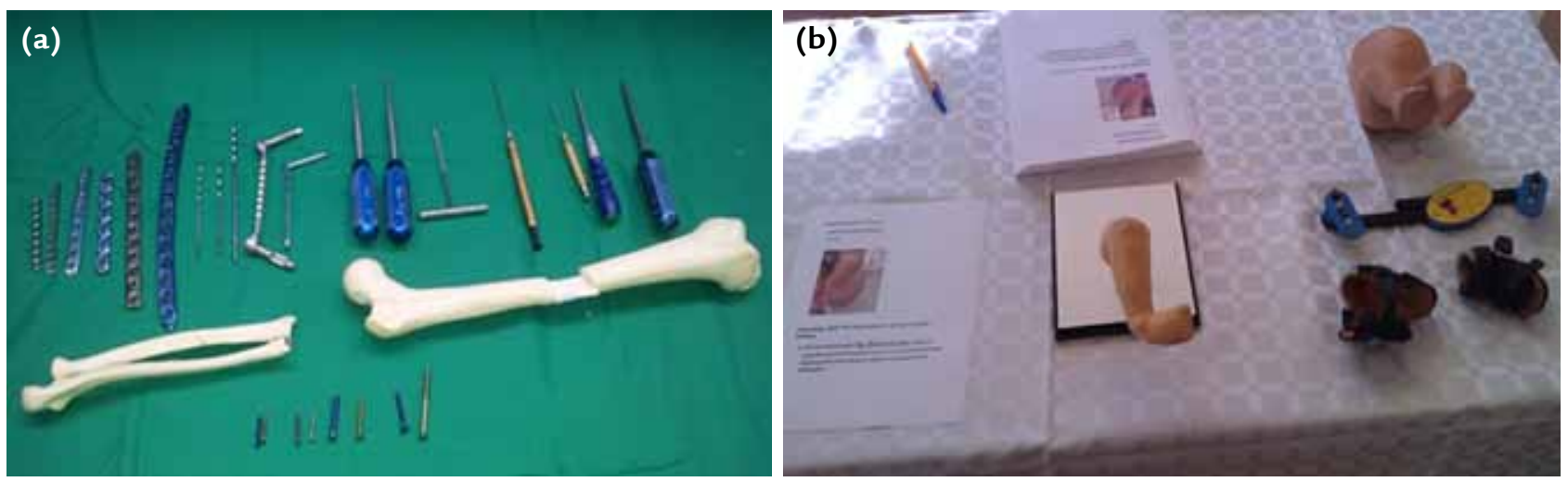

Şekil 7. a, b. TOTEK ikinci aşama sınavı cerrahi planlama ve beceri istasyonları. 


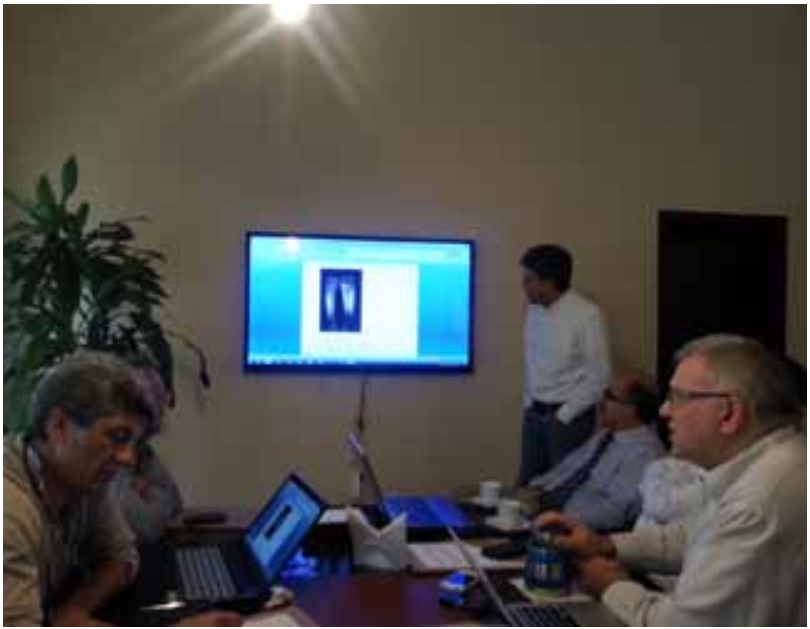

Şekil 8.TOTEK ikinci aşama sınav öncesi soru analizi.

CORE 1: Kart açma sorusu olup, yanlış cevaplarda aday eksi puan almaktadır. (2013 - vertebra travması; 2014 - enfeksiyon)

CORE 2: Kart açma sorusu olup, yanlış cevaplarda aday eksi puan almaktadır. (2013 - el cerrahisi; 2014 - tümör)

OSCE 1: Onam sorusu olup, hasta yakını olarak model kişiler rol almaktadır (2013 - enfeksiyon / gazlı gangren; 2014 - artroplasti)

OSCE 2: Muayene sorusu olup, hasta yakını olarak model kişiler rol almaktadır. (2013 - Alt ekstremite alanında ayak muayenesi; 2014 - üst ekstremite el bileği)

OSCE 3: Cerrahi Planlama (2013 - artroplasti / total kalça protezi; 2014 - alt ekstremite yüksek tibial osteotomi).

OSCE 4: Cerrahi Beceri (2013 - travma / plaklama teknikleri; 2014 - olekranon kırığı gergi bandı)

Anatomi bilgisi cerrahi pratik için temel olup, hem hastanın değerlendirilmesinde hem de tedavisinde önemli bir yer tutar. Radyoloji ile birlikte, ortopedi ve travmatoloji klinik pratiğinin rutininde yer almaktadır. ${ }^{[24]}$ OSCE, klinik konular için çok istasyonlu bir sınav formudur. ${ }^{[25]}$ ABD, Kanada, Ingiltere, Avustralya, Yeni Zelanda ve diğer bazı ülkelerde tıp fakülteleri ve yetkinlik lisansı için klinik becerilerin değerlendirilmesi yöntemi, şu anda OSCE sistemidir. ${ }^{[26]}$ OSCE, klinik beceriyi ölçmede klasik muayeneden daha geniş kapsamlı olup, çok sayıda aday nispeten kısa bir zaman içinde test edilebilir. ${ }^{[27]}$ OSCE sınavlarının güvenilirlik, geçerlilik, objektiflik ve pratikliği; istasyonların sayısı, yapılandırılması, skorlama yöntemleri, (kontrol listesi ve/veya global skorlama) ve aday sayısına dayanmaktadır. ${ }^{[17]}$ Adayın istasyondan istasyona değişebilen performans farklılıkları en fazla ölçüm hatası nedenidir. ${ }^{[28]}$ Bunu

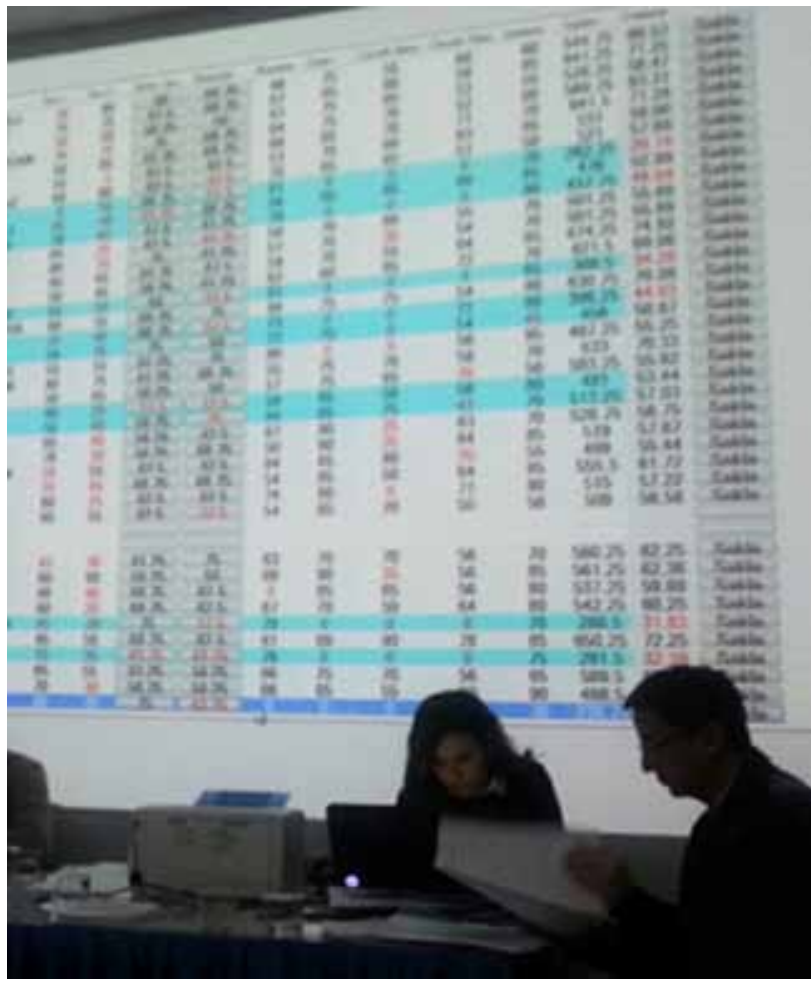

Şekil 9. TOTEK ikinci aşama sınavı sonrası veri analiz salonu.

önlemek için çok sayıda istasyon, çok sayıda değerlendirici ve iyi hasta standardizasyonu OSCE sınavlarını olumlu etkiler. ${ }^{[29]}$ Uzun sınav, performansı olumsuz etkiler, ${ }^{[19,29,30]}$ ek olarak aynı zaman diliminde daha fazla sayıda hasta problemi - konu örnekleme imkanını kısıtlar; ${ }^{[18]}$ fakat aday hakkında daha fazla bilgi verir. ${ }^{[18]}$ Adayın yorgunluğu, heyecanı, gözlemcinin yorgunluğu, ölçüm güvenilirliğini etkiler. ${ }^{[19,29]}$ Daha yüksek gözlemciler arası güvenilirlik için, OSCE sınavları çok sayıda istasyon içermeli ve diğer değerlendirme yöntemleri ile kombine edilmelidir. ${ }^{[30]}$ Sınav güvenilirlik katsayılarını 0,85-0,90'a çıkarmak için 10 OSCE istasyonu ve 3-4 saatlik sınav süresi gerekmektedir. ${ }^{[29]}$ Kontrol listeleri kullanılması sayesinde gözlemciler arası farklııkları azalacak, çok sayıda istasyon ile örneklenecek yeterliklerin sayı ve kapsamı artacaktır. ${ }^{[31]}$ Bu şartları, özellikle de "high stakes exam" denilen diploma vb. belli amaçlarla yapılan sınavlar için, iyi düzenlemek gerekir. ${ }^{[18,29]}$

TOTEK ikinci aşama sınavı; yukarıda belirtildiği şekilde, çok sayıda ve yapılandırılmış istasyonlar içerme, aynı istasyonun dört farklı kulvarda işletilmesiyle aday sayısını düzenleme ve aynı zamanda çok sayıda değerlendiriciye sahip olma, her istasyona uygun miktarda zaman ayırma, OSCE istasyonlarında kontrol listeleri bulundurma, OSCE ile diğer değerlendirme yöntemlerini kombine etme özelliklerinin hepsine sahiptir. 
TOTEK ikinci aşamada başarılı olma koşulu; en çok iki istasyondan başarısız olma ve her bir istasyon puanının 50 veya 50 'den fazla olması şeklindedir; adayların ortalama \%80'i bu barajı geçmektedir (Tablo 5 ve 6). ikinci aşama sınavdan başarılı olamayan adaylar, daha sonraki yıllarda ilk aşama sınavına girmeden 10 yıl içinde toplam üç kez olacak şekilde, ikinci aşama sınavına girebileceklerdir. ${ }^{[5]}$

2010 TOTEK Yeterlik Sınavı sonrası, adaylar tarafından dokuzlu Likert ölçeği ile sınavı değerlendirmeleri istendiğinde, sınavın zorluğu açısından adayların ortada kaldıkları, sınavın süresi, hazırlanışı, soruların konulara dağılımı, bilenle bilmeyeni ayırt etme özelliği yönlerinden iyi bir sınav olduğu görüşü ifade edilmiştir. ${ }^{[17]}$

EBOT ikinci aşama sözlü sınavı, beş ayrı istasyondan oluşmaktadır (Tablo 7). EBOT sınavında, her bir istasyon 30 dakika sürmekte, bu nedenle bir adayın sınavı 2,5 saatte tamamlanmaktadır. Adayların iki güne paylaştırılması nedeniyle, sınav iki tam günü kapsamaktadır. Adaylar aynı anda salona alınarak, farklı masalardan oluşan istasyonlarda yaklaşık 45 sınav yapıcı tarafından değerlendirilmektedir (Şekil 10). Otuz

Tablo 5. TOTEK ikinci aşama sınavı başarı yüzdeleri[ ${ }^{[5]}$

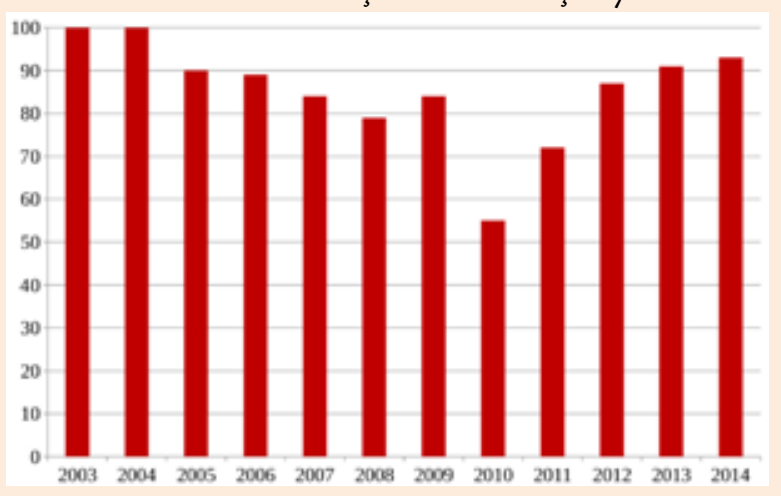

Tablo 6. TOTEK Yeterlik Sınavı, yıllara göre başarı yüzdeleri[ ${ }^{[5]}$

\begin{tabular}{lcc}
\hline & 1. sınav başarısı (\%) & 2. sınav başarısı (\%) \\
\hline 2006 & 31,8 & 89,3 \\
2007 & 54,4 & 83,6 \\
2008 & 32,9 & 78,9 \\
2009 & 29,7 & 84,4 \\
2010 & 79,8 & 54,8 \\
2011 & 40,2 & 61,3 \\
2012 & 39,4 & 86,7 \\
2013 & 45,8 & 91.0 \\
2014 & 47 & 93
\end{tabular}

dakikalık aralıklarla, zil çaldıkça istasyon değiştirilmektedir. Her istasyonda iki sınav yapıcı bulunmakta ve bunlardan biri 15 dakika süresince sorularını sorarken, diğeri adayın cevaplarını puanlamakta, daha sonra diğer değerlendirici aynı görevi devralmaktadır. Aynı istasyonun iki ayrı değerlendirici tarafından değerlendirilmesi, güvenilirliğe olumlu katkı sağlamaktadır. ${ }^{[19]}$ Üzerinde önceden anlaşılmış ve puanlanmış kontrol listeleri bulunmamakla birlikte, usulüne göre hazırlanmış “üç sorulu sözlü" (three question viva) tekniğinde hazırlık sorusu, odak sorusu ve yetkinlik sorularından beklenen yanıt, soru kartına yazılmaktadır. Aday soruları bilemezse, kaçış sorusu (adayın sorulan soruyu daha basitçe anımsaması sağlanacak tarzda) ile bir sonraki soruya geçilir. Her sınav yapıcı, 15'er dakika boyunca kendi soru kartları (portfolyosundaki olgu örnekleri) üzerinden yaklaşık 6-10 olgunun, her birinde en az üç soru ile değerlendirilmesini sağlar. Her olguda, önce ısınma soruları ile başlanmakta, daha sonra giderek adayın analiz yapma ve karar verme becerilerini de ölçecek şekilde daha zor ikinci ve üçüncü aşama soru gruplarına geçilmektedir. ${ }^{[32]}$

Tablo 7. EBOT ikinci aşama sözlü sınavı istasyonları
1. Yetişkin ortopedi ve travmatolojisi - Üst ekstremite
2. Yetişkin ortopedi ve travmatolojisi - Alt ekstremite
3. Yetişkin ortopedi ve travmatolojisi - Vertebra
4. Çocuk ortopedi ve travmatolojisi
5. Temel Bilimler: Biyomekanik, istatistik, metodoloji ve sonuca
dayalı tıp

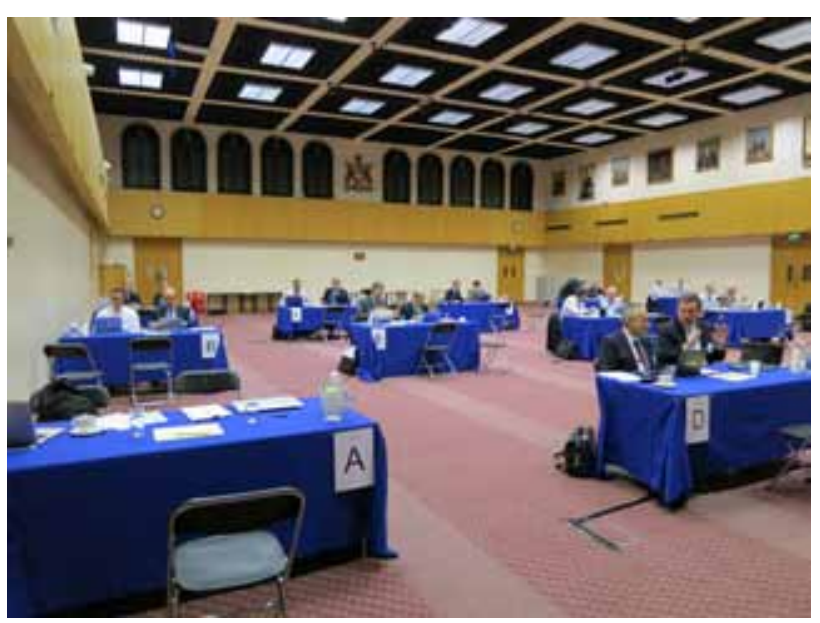

Şekil 10. EBOT ikinci aşama sınavı istasyonları (tüm alt başlıklar). 
EBOT sözlü sınavında, beş istasyonunun her birinden geçme notu altı puan olup, tüm istasyonların toplamı en az $30(5 \times 6)$ olmalıdır. l̇yi performansla geçiş notu, 7; sıra dışı performans notu 8 olarak puanlanırken; başarısızlık notu 5; ciddi başarısızlık notu ise 4'tür. İki istasyondan birden 4 alan aday, kesin olarak başarısız kabul edilmektedir. Eğer tek bir istasyonda 5 puan alındıysa sınav sonrası komite toplantısında adayın durumu yeniden tartışılarak, diğer istasyonlardaki performansı dinlenildikten sonra yükseltilme kararı verilebilir. Toplamda 30 puan aldığı halde iki istasyonda geçer not (6) altında alanlar başarısız sayılmaktadır. Sözlü sınavı geçemeyen adaylar bir sonraki yıl sözlü sınava tekrar girme hakkına sahipler. Ancak izleyen yılda sözlü sınava girmeyen adayın, daha sonra yeniden ilk aşamadan başlaması zorunludur. Sınavı geçen adaylar "Fellow of European Orthopedics and Traumatology" ünvanını kazanırlar. Çalışmak için ön şart koşulmasa da, Avrupa içinde oldukça prestijli bir diploma olarak kabul edilmektedir. ${ }^{[6,9]}$

2009'a kadar 10-15 adayın ilk aşamaya başvurduğu EBOT yeterlik sınavlarına, 2009-2010 yılları arasında 30; 2011 ve sonrasında ise $60-70$ civarı aday başvurmuştur. Başarılı sonuç elde edenlerin oranı \%46-74,3 arasındadır. Avrupa Birliği ülkeleri ve dahil olmayanların başvuru sayısı ve başarı oranları da benzerdir (Tablo 8). ${ }^{[7]}$ Bugüne kadar 200 civarı katılımcı EBOT fellowship diplomasını kazanmış olup, yaklaşık yarıya yakını Avrupa Birliği vatandaşı olmayanlar, \%1'inden daha azı kadın fellow'lardır. ${ }^{[6]}$

Bazı yıllarda EFORT kapsamındaki ülkelerin uzmanlık dernekleri tarafindan belirlenen temsilcilere,
EBOT ikinci aşama sınavında sınav yapıcı olabilmek için kapsamlı bir eğitim verilmektedir. ${ }^{[33]}$ Bu eğitimde sınav kuralları yanı sıra soru sorma teknikleri, adayları yönlendirmeyen nötr tavırlarla sürdürme gerekliliği, değerlendirmenin püf noktaları gibi konular üzerinde de durulmaktadır.

Önümüzdeki yıllarda EBOT sınavına bazı değişiklikler getirilmesi planlanmaktadır. Sınavın aynı gün değişik dillerde ve merkezlerde yapılmasının yanı sıra, profesyonel davranış ve klinik yetileri ölçebilecek üçüncü bir aşama daha eklenerek klinik bir sınav yapılması gündemindedir. Bu sınav yerel dillerde, üç sınav yapıcı (iki, yerel; bir, EBOT adına yerel dili konuşan) tarafından, her biri 10'ar dakikalık iki kısa olgu (muayene ve tartışma), her biri 15'er dakikalık dört uzun olgu (hikaye, muayene ve tartışma) şeklinde planlanmaktadır. ${ }^{[7]}$ Ancak bu taslağın farklı ülkelerdeki klinik muayene kültürünü bilmemek, sınavda kullanılacak hastalarla ilgili hukuki süreçler, sınavda işbirliği için hastanın uyumu, Avrupa Birliği vatandaşı olmayan ülkelerin başarılı adaylarının Avrupa'da çalışma kısıtlılığı, Avrupa eğitim programının sonuna resmi olarak ekleyebilme zorluğu gibi dezavantajları bulunmaktadır. ${ }^{[6]}$

\section{SONUÇ}

Dünya üzerinde örneklerini izlediğimiz gibi TOTEK ve EBOT yeterlik sınavları aynı amaca hizmet etmektedirler. Her iki sınavın da benzer şekilde 10 yıldan fazladır süregelen uzun soluklu tecrübeye sahip olduğu görülmektedir. TOTBID-TOTEK, 2003 yılından itibaren

Tablo 8. EBOT sözlü sınavı başarı oranları

\begin{tabular}{|c|c|c|c|c|c|}
\hline $\begin{array}{c}\text { EBOT } \\
\text { Sinav Yılı }\end{array}$ & Sınav Yeri & $\begin{array}{c}\text { Giren } \\
\text { aday sayısı }\end{array}$ & $\begin{array}{l}\text { Başarılı olan } \\
\text { aday sayısı }\end{array}$ & $\begin{array}{c}\text { Başarışız olan } \\
\text { aday sayısı }\end{array}$ & $\begin{array}{l}\text { Başarı } \\
\text { yüzdesi }\end{array}$ \\
\hline 2001 & Rodos - Yunanistan & 11 & 8 & 3 & $73 \%$ \\
\hline 2002 & Stockholm - İsveç & 16 & 10 & 6 & $63 \%$ \\
\hline 2003 & Amsterdam - Hollanda & 12 & 9 & 3 & $75 \%$ \\
\hline 2004 & Berlin - Almanya & 15 & 10 & 5 & $67 \%$ \\
\hline 2005 & Madrid - İspanya & 10 & 5 & 5 & $50 \%$ \\
\hline 2006 & Torino - İtalya & 18 & 12 & 6 & $67 \%$ \\
\hline 2007 & Viyana - Avusturya & 12 & 7 & 5 & $58 \%$ \\
\hline 2008 & Cenevre - İsviçre & 13 & 6 & 7 & $46 \%$ \\
\hline 2009 & Brüksel - Belçika & 31 & 15 & 16 & $48 \%$ \\
\hline 2010 & Lizbon - Portekiz & 35 & 25 & 10 & $72.5 \%$ \\
\hline 2011 & Paris - Fransa & 60 & 39 & 21 & $66.5 \%$ \\
\hline 2012 & Dublin - Irlanda & 78 & 58 & 20 & $74,3 \%$ \\
\hline 2013 & Barselona - İspanya & 84 & 62 & 22 & $74 \%$ \\
\hline
\end{tabular}


TOTEK yeterlik sınavı, 2009'dan itibaren Uzmanlık Eğitimi Gelişim Sınavı (UEGS) tecrübeleriyle; aynı şekilde EBOT da 2001 yılından itibaren EBOT Fellowship Exam (yeterlik sınavı), 2011 yılından itibaren ise EBOT Interim Exam (asistan sınavı) ile bu uygulamalarını büyük çaba ve özveriyle gerçekleştirmektedir. ${ }^{[2,5,6,23]}$

Ancak her iki sınav kıyaslandığında, TOTEK sınavının; EBOT'un gelecekte planladığı beceri ve tutumu ölçebilen üçüncü basamak modüllerini (Onam - Muayene - Cerrahi Planlama - Cerrahi Beceri istasyonlarını) zaten uzun yıllardır içermesi, yine TOTEK sınavında literatürde de $\mathrm{e}^{[1,16,25,27-29,31,34-36]}$ geniş bir onay alan OSCE tipi soruların kullanılması, sözlü aşama istasyon sayısının ve her istasyondaki soru sayısının yüksekliği ve bu nedenle adayı oldukça iyi değerlendirme fırsatı vermesi, EBOT'a nazaran temel üstünlükleridir ve geçerliliğini arttırmaktadır. ${ }^{[29,30]}$ Yine, kapsam geçerliliği yönünden oldukça iyi değerlendirilmiş olması da önemli avantajlarıdır. Ayrıca, EBOT soruları konusunda fikir veren ulaşılabilir bir kaynak bulunmamasına karşın, ${ }^{[6]}$ TOTEK tarafından çıkarılan yeterlik sınavlarına hazırlanmada yol göstermek amacıyla (daha önceki sınavlarda çıkan soru ve açıklamalı cevaplarını da içeren) bir kaynak kitap ve yanı sıra ÇEP konularını içeren her yıl güncellenen kitaplar bulunmaktadır. ${ }^{[20,37]}$ Sınav kapsamındaki konularla ilgili güncel derleme bilgilerine ulaşabilmek amacıyla, TOTEK 2003'den beri Çekirdek Eğitim Programı (ÇEP), EBOT 2009'dan itibaren Clinical Review Course (CRC) düzenlemektedir. ${ }^{[6]}$ ÇEP kurslarına katılan adayların başarı yüzdesi, katılmadan sınava girenlere göre oldukça yüksektir (2014 için; ÇEP kursuna katılarak sınava giren 36 kişiden \%75'i başarıIı, katılmayan 124 kişiden \%39'u başarılı).

Sınav maliyetleri düşünüldüğünde, OSCE istasyonları pahalıdır ve emek yoğun teknoloji gerektirir. ${ }^{[30]}$ Kabul edilebilir bir güvenilirlik için, OSCE sınavlarında aday başına Amerika'da $\$ 200$ ile Kanada'da \$1080 arası bütçe gerekmektedir. Her öğrenci başına model hasta maliyeti $\$ 7$ olup, sınavın her saati öğrenci başına \$15'a mal olmaktadır. ${ }^{[30]}$ Yine de, OSCE içermesine rağmen TOTEK sınavı, hem katılımcılar için yüksek sınav masrafları (uluslararası yol-otel vb.) gerektirmeme hem de sınav düzenleyiciler yönünden gözetmenlerinin tamamının aynı şehirlerden seçilebilme avantajlarına sahiptir. Bunun yanı sıra, maket, teknik donanım, salon, nakliye vb. içerikleri, ülkemizin avantajlı koşulları ve planlaması sayesinde, hem katılımcılar hem de sınav organizasyonu açısından daha maliyet-etkin görünmektedir.

Ek olarak, TOTEK sınavının; EBOT'a giren tüm Avrupa adayları gözönüne alındığında dahi çok yüksek katılım oranları; bu katılım yüksekliğine hemen cevap verebilecek donanım ve organizasyon kapasitesi; sınava girmek isteyen aday sayısına sınırlama getirilmediğinden firsat eşitliği sağlaması; olası adaylara da sınav tekniği hakkında fikir verecek şeffaflıkta paylaşılması gibi olumlu özellikleri göze çarpmaktadır. Her iki sınavın yapı geçerliliği, kapsamlılık geçerliliği, psikometrik nitelikleri yönünden bir kıyaslama yapılmasının, ancak EBOT sınavı analizlerinin tıp eğitimcileri tarafından incelenmesi sonrasında sağlanabileceği açıktır. İyi bir testi oluşturan geçerlilik, güvenilirlik, objektiflik, pratiklik gibi kriterlerin tamamını mükemmel olarak sağlayan bir sınav maalesef bulunmamaktadır. ${ }^{[30]}$ Bazen, eldeki imkanlar (insan, para, zaman), yöntem ve değerlendirme kalitesi (güvenilirlik, geçerlilik, objektiflik ve pratiklik) arasında bir uyuşma sağlanması gerekmektedir. ${ }^{[30]}$

Bunun yanı sıra, eğitim kurumlarımızdaki eğitimin kalitesini sürdürme ve dolayısıyla hekimin güvenilirliğini koruma sorumluluğunu taşımakta olan tüm eğitmenlerin; sınavın ölçüm güvenilirliğini korumak adına, soru havuzuna kaliteli sorularla katkıda bulunması oldukça önem taşımaktadır. Her zorluk düzeyi için ayırt ediciliği yüksek sorular hazırlamak ve bu amaçla düzenlenen eğitim ve çalıştaylara katılmak, daha verimli sonuçlar elde etmemizi sağlayacaktır. Sınavda görev alan eğitmenlerin de değerlendirici tutarlılık ölçümlerini -belli aralıklarda bir araya gelerek- araştırmaya ve varsa farklılıkları kabul edilebilir ölçüye getirmelerini temin edecek çalışmalara da ihtiyaç olabilir.

Gelecek planlarına baktığımızda; TOTEK diplomasının Avrupa'da EBOT ile eşdeğerliğe sahip olması yönünde çalışmalar yıllardan beri devam etmekte olup, buna hizmet etmek üzere EBOT sınavının Türkiye'de yapılması planları ağılık kazanmaktadır. Ulusal sınavımızın da EBOT'a tanıtılması önümüzdeki hedeflerdendir. Tüm bu hedeflerde paydaşlarımızın en değerlisi; tıpta güvenilir ve güncel bilgiye, yetkin ve doğru uygulamalara sahip olmanın önemine inanan hekimlerimizdir. Bunu sağlamak adına, atama-yükseltme kriterlerinde TOTEK sertifikasının dikkate alınması yönündeki TOTEK'in tavsiyelerinin ve gelişmiş ülkelerdeki hekimlik ön şartlarından olan resertifikasyonun benimsenmesinin ülkemiz ortopedi ve travmatolojisini daha da ileriye taşıyacağı aşikârdır.

\section{Teşekkür}

$\mathrm{Bu}$ makalenin hazırlanması esnasında verilerini ve grafiklerini içtenlikle paylaşan Başkent Üniversitesi Ortopedi ve Travmatoloji Anabilim Dalı öğretim üyesi, 2012-14 TOTEK yeterlik sınavı yürütücüsü Sayın Prof. Dr. Illhami Kuru başta olmak üzere, yazıda bahsi geçen sınavların psikometrik özellikleri konusundaki yorumlarımızı nezaketle değerlendiren, Ege Üniversitesi Tıp Fakültesi, Tıp Eğitimi Anabilim Dalı öğretim 
üyeleri Prof. Dr. Halil Ibrahim Durak ve Doç. Dr. Ayhan Çalışkan, Hacettepe Üniversitesi, Tıp Eğitimi ve Bilişimi Anabilim Dalı öğretim üyesi Doç. Dr. Melih Elçin ve Öğr. Gör. Arif Onan'a teşekkürlerimizi sunarı.

\section{Bilgilendirme}

Emel Gönen, TOTEK, EBOT yeterlik sınav yapıcısıdır; Haluk Berk, UEMS-Ortopedi seksiyonu TOTBID temsilcisi ve EBOT sınav yapıcısıdır. Her iki yazarın da çalışma sonuçları ile ilgili hiçbir maddi bir çıkar çatışması bulunmamaktadır.

\section{KAYNAKLAR}

1. Black KP, Alman BA, Levine WN, Nestler SP, Pinney SJ. Orthopaedic resident education--it's a whole new game: "If I'm going to be a spine surgeon, why do I need to learn how to reconstruct an anterior cruciate ligament?": AOA critical issues. J Bone Joint Surg Am 2012;94(13):e96. CrossRef

2. Caliskan A, Aydogdu S, Gonen E, Oztuna V. Orthopedics and Traumatology Progress Test: A nationwide, on-site, intraining examination. Free Paper No: 13-5349, 14th EFORT Congress, 5-8 June 2013, Istanbul.

3. Gönen E. Ortopedi ve Travmatoloji III. ve IV. Uzmanlık Eğitimi Gelişim Sınavı Raporu 2012-2013, Türk Ortopedi ve Travmatoloji Eğitim Konseyi (TOTEK) VI. Dönem Kitabı. 36-52.

4. Gönen E. Yeniden Belgelendirme Komisyon Raporu 20122013, Türk Ortopedi ve Travmatoloji Eğitim Konsey (TOTEK) VI. Dönem Kitabı. p.32-5.

5. Kuru i. Türk Ortopedi ve Travmatoloji Birliği Derneği (TOTBID) - Türk Ortopedi ve Travmatoloji Eğitim Konsey (TOTEK) Yeterlik Sınavı 2013 1. ve 2. Aşama Raporu, Türk Ortopedi ve Travmatoloji Eğitim Konsey (TOTEK) VI. Dönem Kitabı. p.53-68.

6. Makinen TJ, Madanat R, Kallio P, Mimerio J, Kiviranta I. The current state of the fellowship examination of the European Board of Orthopedics and Traumatology (EBOT). Eur Orthop Traumatol 2014;5:217-20. CrossRef

7. Berk H. Yurtdışı yeterlik sınavlarına ülkeler bazında bakış. TOTEK Paneli. 23. Ulusal Ortopedi ve Travmatoloji Kongresi. 29 Ekim - 3 Kasım 2013, Antalya.

8. Orthopaedic Residency Training Survey. Federation of Orthopaedic Trainees in Europe, FORTE. Available at: https:// www.surveymonkey.com/s/2YSF7Y6 Accessed: 16 Sep 2014.

9. Mineiro J. The first decade of the fellowship examination of the European Board of Orthopaedics and Traumatology (EBOT Exam): a prestigious orthopaedic-traumatology qualification in Europe. Orthop Today Eur 2011;1:9.

10. Mineiro J. The EBOT examination in the new formatEuropean board certification. Orthop Today Eur 2012;1:8.

11. The European Board of Orthopaedics and Traumatology (2014) EBOT examination Available at: http://www. ebotexam.org/ Accessed: 16 Sep 2014.

12. EBOT testing with Pearson-VUE. Available at http://www. pearsonvue.com/ebot/ Accessed: 16 Sep 2014.

13. PVTC Technology Available at http://www.pearsonvue.com/ test-center/technology.asp Accessed: 16 Sep 2014.

14. Pearson VUE, PVTC Technical Requirements. Available at: http://www.pearsonvue.com/pvtc/technical_reqs.pdf Accessed: 23 Sep 2014.
15. Case SM, Swanson DB. Constructing Written Test Questions For the Basic and Clinical Sciences, 3rd ed. National Board of Medical Examiners (NBME). Philadelphia 2002.

16. Norcini JJ. Setting standards on educational tests. Med Educ 2003;37(5):464-9.

17. Benli T. Yeterlik Sınavı Raporu, Türk Ortopedi ve Travmatoloji Eğitim Konsey (TOTEK) 2009-2011 V. Dönem Kitabı. p.55-70.

18. Miller GE. The assessment of clinical skills/competence/ performance. Acad Med 1990;65(Suppl):S63-7.

19. Cascarini L. Surviving a clinical exam: a guide for candidates. J R Soc Med 2005;98(4):174-77.

20. Kuru i, editör. TOTEK Yeterlik Sınavına Hazırlık. Ankara: Bayt Bilimsel Araştırmalar Basın Yayın ve Tanıtım Ltd. Şti; 2013.

21. TOTEK yeterlik sınavı 1. aşama soru ve cevapları 14 Eylül 2014. Available at: http://www.totbid.org.tr/upload/ files/2014\%20board\%20soru\%20ve\%20cevaplari\%288\%29. pdf Accessed: 16 Sep 2014.

22. TOTEK Yeterlik Sınavları Arşivi. Available at: http://totek. totbid.org.tr/Content.aspx?p=2092 Accessed: 16 Sep 2014.

23. Kuru i. Board Deneyimi. Soru Hazırlama Ölçme ve Değerlendirme Çalıştayı. 25 Ekim 2014.

24. Bernstein J. Orthopaedic residency: how do you know when the "cake is done?". Clin Orthop Relat Res 2013;471(1):912. CrossRef

25. Harden RM, Stevenson M, Downie W, Wilson GM. Assessment of clinical competence using objective structured examination. Br Med J 1975;1(5955):447-51.

26. What is Objective Structured Clinical Examination, OSCEs? Available at: http://www.oscehome.com/What_is_ObjectiveStructured-Clinical-Examination_OSCE.html Accessed: 16 Sep 2014.

27. Ananthakrishnan N. Objective structured clinical/practical examination (OSCE/OSPE).J Postgrad Med 1993;39(2):82-4.

28. Carraccio $C$, Englander R. The objective structured clinical examination: a step in the direction of competency-based evaluation. Arch Pediatr Adolesc Med 2000;154(7):736-41.

29. Turner JL, Dankoski ME. Objective structured clinical exams: a critical review. Fam Med 2008;40(8):574-8.

30. Barman A. Critiques on the Objective Structured Clinical Examination. Ann Acad Med Singapore 2005;34(8):478-82.

31. Newble D. Techniques for measuring clinical competence: objective structured clinical examinations. Med Educ 2004;38(2):199-203.

32. Bulstrode C, Hunt V. Training in practice. Oxford: Skills Unit, Oxford; 2000.

33. 15th EFORT Congress 2014. Comprehensive Review Course (CRC). Available at https://www.efort.org/london2014/ scientific-content/scientific-session-information/crc/ Accessed: 16 Sep 2014.

34. Wallace J, Rao R, Haslam R. Simulated patients and objective structured clinical examinations: review of their use in medical education. Advances in Psychiatric Treatment 2002;8:342-50.

35. Wani PD, Dalvi VS. Objective structured practical examination vs. traditional clinical examination in human physiology: student's perception. Int J Med Sci Public Health 2013;2(3):543-7.

36. Zayyan M. Objective structured clinical examination: the assessment of choice. Oman Med 2011;26(4):219-22. doi: 10.5001/omj. 2011.55

37. TOTBID-TOTEK Ortopedi ve Travmatoloji Çekirdek Eğitim Programı, Klinik Gözden Geçirme Kursu Kitabı. Ankara: TOTBID; 2014. 